\title{
Effects of pressure and type of gas on particle-particle interaction and the consequences for gas-solid fluidization behaviour
}

Citation for published version (APA):

Piepers, H. W., Cottaar, E. J. E., Verkooijen, A. H. M., \& Rietema, K. (1984). Effects of pressure and type of gas on particle-particle interaction and the consequences for gas-solid fluidization behaviour. Powder Technology, 37(1), 55-70. https://doi.org/10.1016/0032-5910(84)80006-6

DOI:

10.1016/0032-5910(84)80006-6

Document status and date:

Published: 01/01/1984

Document Version:

Publisher's PDF, also known as Version of Record (includes final page, issue and volume numbers)

\section{Please check the document version of this publication:}

- A submitted manuscript is the version of the article upon submission and before peer-review. There can be important differences between the submitted version and the official published version of record. People interested in the research are advised to contact the author for the final version of the publication, or visit the DOI to the publisher's website.

- The final author version and the galley proof are versions of the publication after peer review.

- The final published version features the final layout of the paper including the volume, issue and page numbers.

Link to publication

\footnotetext{
General rights

- You may freely distribute the URL identifying the publication in the public portal. follow below link for the End User Agreement:

www.tue.nl/taverne

\section{Take down policy}

If you believe that this document breaches copyright please contact us at:

openaccess@tue.nl

providing details and we will investigate your claim.
}

Copyright and moral rights for the publications made accessible in the public portal are retained by the authors and/or other copyright owners and it is a condition of accessing publications that users recognise and abide by the legal requirements associated with these rights.

- Users may download and print one copy of any publication from the public portal for the purpose of private study or research.

- You may not further distribute the material or use it for any profit-making activity or commercial gain

If the publication is distributed under the terms of Article $25 \mathrm{fa}$ of the Dutch Copyright Act, indicated by the "Taverne" license above, please 
EFFECTS OF PRESSURE AND TYPE OF GAS ON PARTICLE-PARTICLE INTERACTION AND THE CONSEQUENCES FOR GAS-SOLID FLUIDIZATION BEHAVIOUR

H.W.Piepers, E.J.E.Cottaar, A.H.M.Verkooijen and K.Rietema

Department of Chemical Engineering

Eindhoven liniversity of Technology, The Netherlands

\section{Abstract}

The fluidization behaviour of cracking catalyst has been studied up to pressures of 15 bar with different fluidization gases ( $\mathrm{Ar}, \mathrm{N}_{2}, \mathrm{H}_{2}$ ). A number of parameters of both the homogeneous and heterogeneous fluidized bed has been examined experimentally.

The experimental results reveal that the minimum fluidization velocity $\left(U_{\mathrm{mf}}\right)$ is independent of the pressure. The bubble point velocity $\left(\mathrm{U}_{\mathrm{bp}}\right)$ and the maximum bed expansion $\left(H_{b p}\right)$ at this velocity increase with increasing pressure. This also holds for the dense phase voidage ( $\varepsilon_{d}$ ) and the dense phase gas velocity $\left(U_{d}\right)$ in the bubbling bed. The bubbie size decreases drastically with increasing pressure. However, the above-mentioned parameters are also strongly dependent on the type of fluidization gas used.

The cohesion constant of the powder was measured, using a tilting bed technique. The results reveal that the cohesion constant increases with increasing pressure. Analysis of the results of adsorpiion measurements of the different gases to the solid reveals for the adsorption as well as for the cohesion and for the beu expansion the same pressure dependence.

It is believed that the gas adsorption influences the cohesion between the particles and hence the elasticity modulus introduced by Rietema and Mutsers $[1,2]$. The increasing elasticity modulus with increasing pressure also explains the increasing bed expansion with pressure.

\section{Introduction}

The interest in fluidized bed behaviour at hign pressures has increased considerably in the last years, because knowledge of the fluidization behaviour at high pressures is important to predict the bed performance as a chemical reactor [3].

Many investigators [4-9] who studied the effect of pressure or gas density on fluidized bed behaviour reported that high pressure results in an increase of bed expansion and minimum bubble point velocity $U_{b p}$, for group A powders of Geldart's classification [10]. From the results of their experiments on 48 gas-solid systems Abrahamsen and Geldart [11] 
correlated the minimum bubble point velocity, $U_{b p}$, and the maximum non-bubbling bed expansion ratio, $\mathrm{H}_{\mathrm{bp}} / \mathrm{H}_{\mathrm{mf}}$. According to this correlation

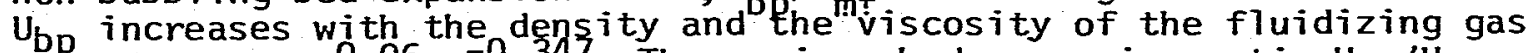

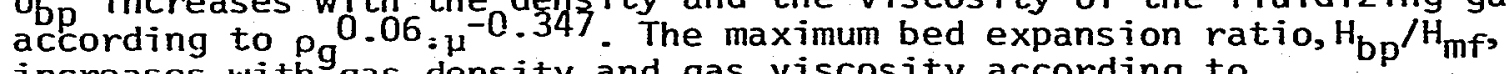
increases ${ }^{\text {wj }} \mathrm{ft}^{\mathrm{g}}$ gas density and gas viscosity according to

The effect of pressure on bubbling has also been studied extensively $[5,8,9,12-14]$. Evidence is available that in beds of fine powders increasing pressure leads to the occurrence of smaller bubbles. A qualitative explanation [12] has been given in terms of increased bubble splitting by Taylor instabilities with increased dense phase expansion. Another explanation was advanced in terms of bubble stability based on particle pick-up from the lower surfaces of the bubbles $[8,9]$.

However, none of the investigators explain why for fine powders the non-bubbiing bed expansion increases with increasing pressure. There is also no agreement on the mechanism that is determining the decreasing bubble size with increasing pressure.

In both phenomena, however, the properties of the dense phase play an important part. Rietema and Mutsers [1,2] assert that interparticle cohesion forces play an important part in the non-bubbling bed expansion of iine powders. According to these authors the interparticle cohesion forces give rise to a powder structure in the bed with a certain mechanical strength, even in the expanded state. They developed a theory in which they assigned a certain elasticity, $E$, to the powder structure, resulting from the interparticle cohesion forces. From this theory they derived a criterium relating the elasticity modulus $E$ of the bed to the voidage of the bed, $\varepsilon_{b p}$, at the bubble point velocity

$$
\frac{\rho_{p}{ }^{3} \dot{d}_{p}^{4} g^{2}}{\mu^{2} E_{b p}}=\left\{\frac{150\left(1-\varepsilon_{b p}\right)}{\varepsilon_{b p}^{2}\left(3-2 \varepsilon_{b p}\right)}\right\}^{2}
$$

In a "human centrifuge" Rietema and Mutsers [15] studied the fluidization behaviour at accelerations which exceeded gravitational acceleration. The theory they developed predicts exactly the maximum nonbubbling bed expansion in the centrifugal field.

The aim of the present study is to investigate the influence of pressure and type of gas on non-bubbling and bubbling bed behaviour and to explain this behaviour in terms of interparticle forces. It is believed that adsorption of gases to the solid influences the cohesion between the farticles and hence the elasticity modulus, $E$.

Experimental

Fluid bed experiments

A diagrammatic flowsheet of the fluidization apparatus is shown in figure 1 . The fluidized bed consisted of a glass tube $82 \mathrm{~mm}$ ID, $100 \mathrm{~mm} O D$ and $145 \mathrm{~cm}$ long, which incorporated a porous brass gas distributor. The top and bottom sections were made of brass and the whole system was held tight by means of four compression bars and 0-ring seals.

The fluidizing gas, initially fed from a pressurized cylinder, was circulated in a closed-7oop system by means of a compressor. Before and after the compressor a pressure vessel was installed to dampen flow rate fluctuations. The gas flow rate in the system was measured 


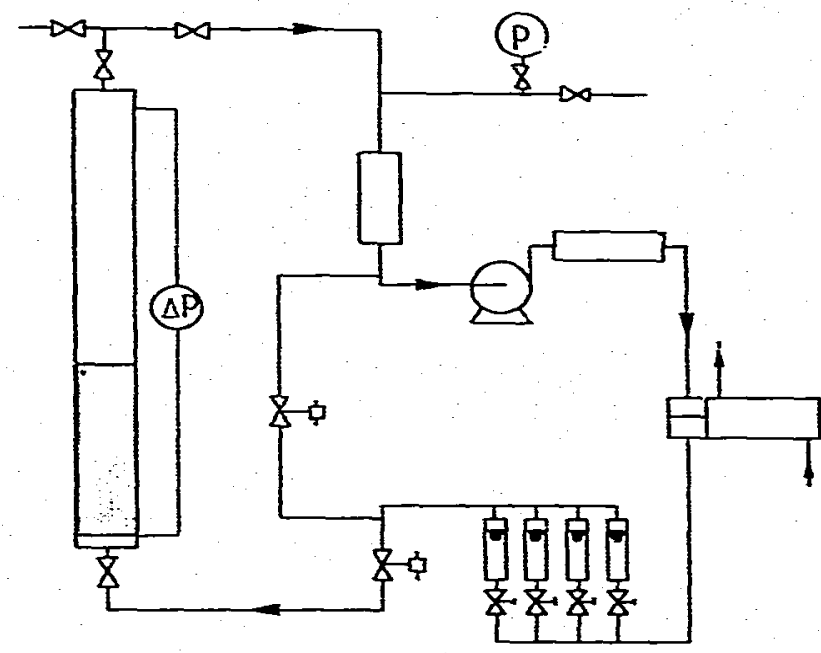

Figure I Schematics of the experimental set-up.

with a set of calibrated rotameters.

Pressure tappings connected to a water manometer were used to measure the pressure drop over the bed and the static pressure was given by a manometer connected to the top section of the bed.

A movable capacitive probe, mounted in the bed, was used to measure the bubble frequency.

The height of the bed was measured by reference to a tape on the outside of the glass tube.

The same batch of cracking catalyst ( $d_{p}=59.4 \mu \mathrm{m}, \rho_{p}=887 \mathrm{~kg} / \mathrm{m}^{3}$ ) was used in a11 experiments. The powder fell in $\mathrm{P}_{\mathrm{Ge}}$ dart's group $\mathrm{A}$ [10]. Hith an average packed bed height of about $60 \mathrm{~cm}$ this powder was f7uidized with $\mathrm{N}_{2}, A r$ and $\mathrm{H}_{2}$, at pressupes up to 15 bar. The physical properties of the gases are given in table 1. At each flow rate, the pressure drop and the bed height were recorded.

Table 1 Fhysical properties of used gases $\left(20^{\circ} \mathrm{C}, 1\right.$ bar $)$

\begin{tabular}{|l|l|l|}
\hline gas & $\begin{array}{l}\text { dersity } \\
\left(\mathrm{kg} / \mathrm{m}^{3}\right)\end{array}$ & $\begin{array}{l}\text { viscosity } \\
\left(\mathrm{Ns} / \mathrm{m}^{2}\right)\end{array}$ \\
\hline $\mathrm{H}_{2}$ & 0.084 & $87.6 * 10^{-7}$ \\
$\mathrm{~N}_{2}$ & 1.165 & $173 * 10^{-7}$ \\
$\mathrm{Ar}$ & 1.662 & $220 * 10^{-7}$ \\
\hline
\end{tabular}

The minimum fluidization velocity, $U_{m f}$ was determined by the intersecting of the two linear portions of the velocity-pressure drop curve. From a graph of the bed height, $H$, against the superficial velocity the bubile point velocity, $\mathrm{U}_{\mathrm{bp}}$, and the maximum bed height, $\mathrm{H}_{\mathrm{b}}$, were determined. The bed voidage was calculated from: 
58

$$
\varepsilon=1-W / \rho_{\mathrm{p}} * \mathrm{H} * \mathrm{~A}
$$

For the heterogeneously fluidized bed, the height of the dense phase, $H_{d}$, the dense phase gas velocity, $U_{d}$, and the bubble hold-up, $\delta$, were calculated from so-called collapse experiments, a method suggested by Rietema [16]. The bed was first fluidized for several minutes at a superficial gas velocity higher than $U_{b p}$. At a given moment, $t=0$, the gas supply to the bed is suddenly shut off and the level of the bed falls quickly to a certain value $H_{1}$, because of the quick release of gas bubbles in the bed. Below this value $H_{1}$, the settling of the bed is much slower (figure 2).

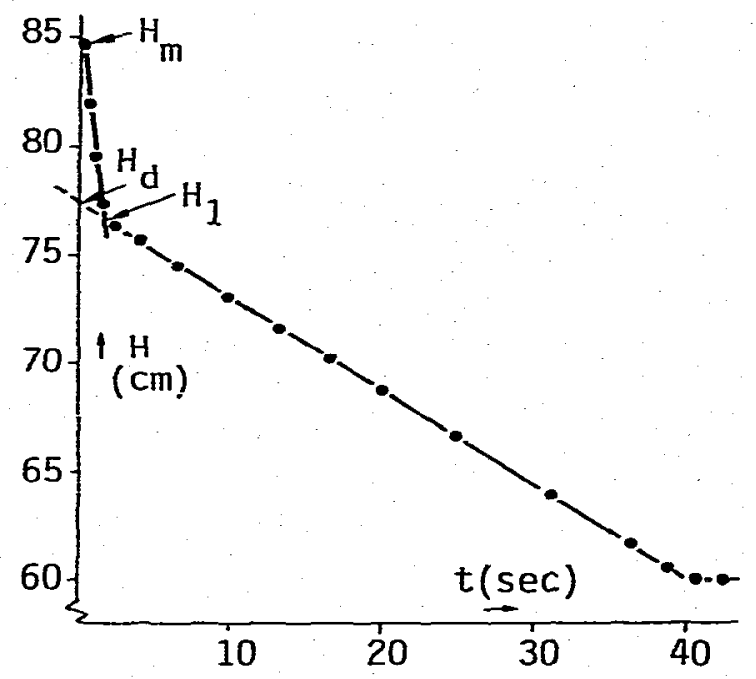

Figure 2 Collapse experiment. Total bed height as function of time.

The collapse experiments were carried out at pressures up to 15 bar for both $\mathrm{N}_{2}$ and $\mathrm{Ar}$. The time and the bed height were continuously recorded on a videofilm. A result of the analysis of a videofilm of such a collapse experiment is shown in figure 2 . The rate at which the top of the bed comes down below $\mathrm{H}_{1},-\mathrm{dH} / \mathrm{dt}$, is equal to the superficial gas velocity through the dense phase, $U_{d}$, before shutting off the gas. The dense phase expansion, $H_{d}$, is obtained by extrapolation towards $t=0$, as shown in figure 2. values of the dense phase voidage, $\varepsilon_{\mathrm{d}}$, were calculated from equation (2).

The bubble hold-up, $\delta$, is defined as the fraction bubble volume/bed volume, and as such may be calculated from

$$
\delta=\left(H_{m}-H_{d}\right) / H_{m}
$$

With $\mathrm{Ar}$ and $\mathrm{N}_{2}$ as fluidizing gas bubble frequencies were measured at a height of $65 \mathrm{~cm}$ above the gas distributor at pressures up to 15 bar and superficial gas velocities up to $5 \mathrm{~cm} / \mathrm{s}$.

Tilting fluidized bed experiments

In classical equipment for the determination of the cohesive and frictional properties of powders relatively large compressive stresses are used. Consequentiy the cohesion of the powder, the shear strength, $\tau$ 
at zero compressive stress $\sigma$, is determined by extrapolation to $\sigma=0$. The tilting fluidized bed is particularly suited to measure the shear strength of powders at low compressive stress. The tilting bed, constructed as an ordinary fluid bed (diameter $10 \mathrm{~cm}$, height $20 \mathrm{~cm}$ ), was mainly fabricated of thick perspex in order to observe the bed material directly. To facilitate pressurized operation the bed was placed in a closed-loop system. The bed could be tilted very slowly and without shocks to an angle $\alpha$ with the horizontal by means of a smoothly running electric motor combined with a speed reducing gear.

when in a fluidized bed a powder layer is formed by collapse from the heterogeneousiy fluidized state and consequently the bed is tilted over an angle $\alpha$ the following forces act upon a layer with height $H$ (figure 3)

$$
\begin{aligned}
& \sigma=\rho_{p}(1-\varepsilon) g H \cos \alpha \\
& \tau=\rho_{p}(1-\varepsilon) g H \sin \alpha
\end{aligned}
$$

It can be seen that the shear strength, $\tau$, is largest at the bottom and failure will occur here first. When at the same time gas is passed through the bed a force due to the pressure drop, $\triangle \mathrm{P}$, also acts on the 1ayer (figure 4). Consequentiy:

$$
\begin{aligned}
& \sigma=\rho_{p}(1-\varepsilon) g H \cos \alpha-\Delta P \\
& \tau=\rho_{p}(1-\varepsilon) g H \sin \alpha
\end{aligned}
$$

From this it will be clear that the shear strength $\tau$ at which failure occurs can be measured with decreasing values of the normal stress by increasing the pressure drop over the powder layer. In this way the cohesion can be determined more accurately.

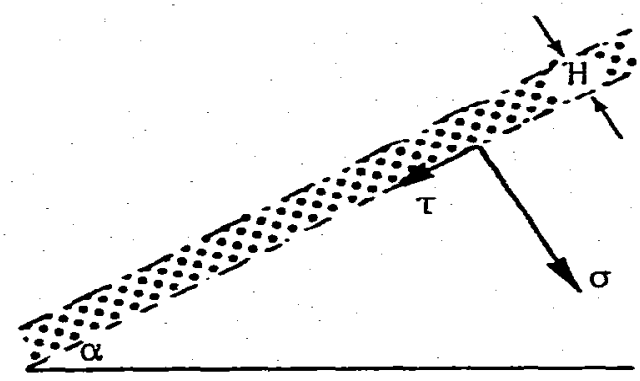

Figure 3 Force balance for a powder layer in a tilting bed (no gas flow).

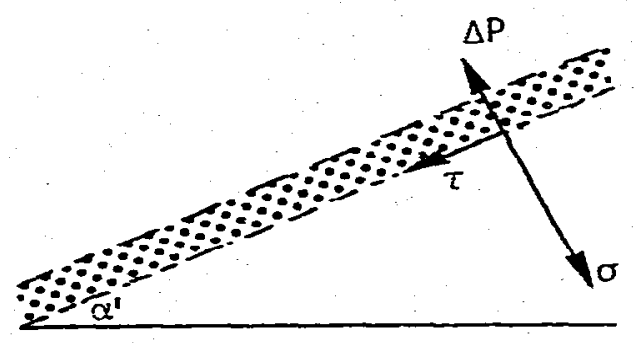

Figure 4 Force balance for a powder layer in a tilting bed (with gas flow).

In order to measure the influence of pressure on the cohesion properly a number of precautions must be taken to eliminate other influencing parameters.

The experiments were done with cracking catalyst in an atmosphere of Ar at pressures up to 11 bar for gas velocities $<U_{m f}$. Care was taken to carry out the experiments with a powder bed of monstant porosity and identical consolidation history. To measure small normal stresses and to avoid wall effects the bed height was $0.02 \mathrm{~m}$. 
60

\section{Analysis of results}

Minimum fluidization velocity $\left(U_{m f}\right)$

For $\mathrm{Ar}$ and $\mathrm{N}_{2}$ the measured values of the minimum fluidization velocity, $U_{\text {mf }}$ within the experimental scatter did not show any systematic dependence on pressure. This is in agreement with the findings of other investigators [4-8] for fine powders. With $\mathrm{H}_{2}$ as fluidizing gas $\mathrm{U}_{\mathrm{f}}$ de reases a little with pressure. This is due to a change in the bed voidage, $\varepsilon_{m f}$. For $H_{2}$ the bed voidage $\varepsilon_{m f}$ decreases a $7 i t t 7 e(4 \%)$ with increasing pressure. On the other hand with $\mathrm{Ar}$ and $\mathrm{N}_{2}$ the bed voidage $E_{m f}$ increases with increasing pressure. This is in agreement with the results of Sobreiro et al. [6] who reported that for a fine powder in a $\mathrm{N}_{2}$ atmosphere $\varepsilon_{\mathrm{mf}}$ seemed to be consistently lower at ambient pressure than at high pressure. However, for all pressures $\varepsilon_{m f}$ was found to increase with increasing gas viscosity. The results (figure 5) could very well be represented by the laminar part of the equation of Ergun [17]:

$$
U_{m f}=\frac{\varepsilon_{m f}^{3}}{1-\varepsilon_{m f}} * \frac{\rho_{p} d_{p}^{2} g}{150 \mu}
$$

From this equation it follows that $\left(U_{m f}\left(1-\varepsilon_{m f}\right)\right) / \varepsilon_{m f}^{3}$ should be independent of pressure.

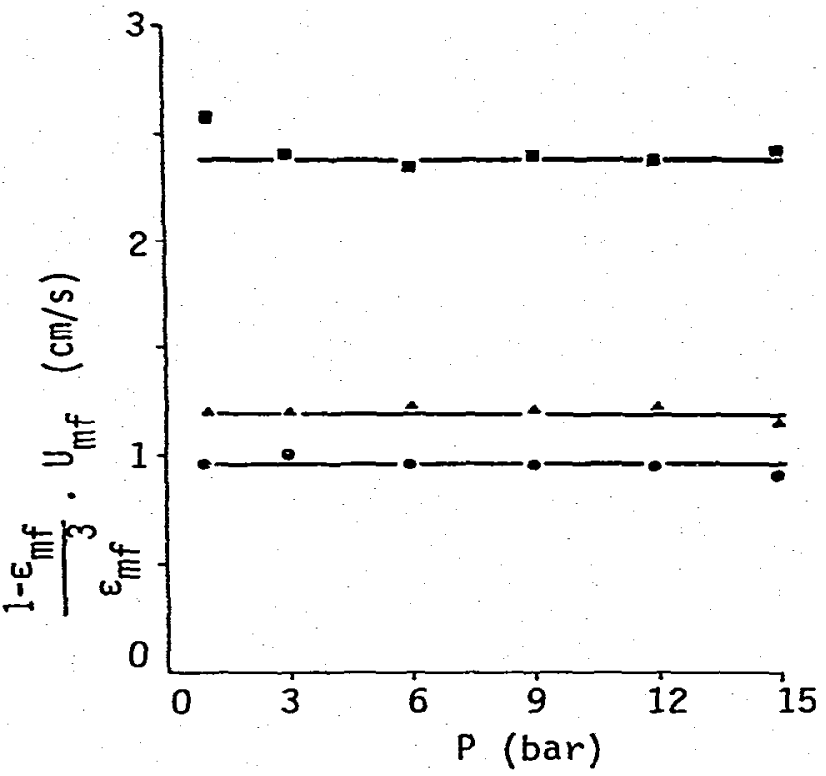

Figure 5 The variation of $U_{m f}$ with pressure $\left(\bullet A r_{,} \Delta N_{2}, H_{2}\right)$.

Bubble point velocity $\left(\mathrm{U}_{\mathrm{bp}}\right)$ and bed voidage $\left(\varepsilon_{\mathrm{bp}}\right)$

The bubble point velocity, $U_{h p}$, showed the characteristic behaviour found in fluidization of grolip $A$ powders, increasing with increasing pressure $[4,6,7]$.

In figure 6 the results of the measurements are given. From this figure it is seen that the type of fluidizing gas has a very strong effect on 
the variation of $U_{b p}$ with pressure. With Ar the variation with pressure is strongest, while for $\mathrm{H}_{2}$ only a very weak dependence on the pressure was found.

The same picture we get for the bed voidage at the bubble point velocity, $\varepsilon_{b p}$. The dependence of $\varepsilon_{p}$ with pressure is shown in figure 7 . The results reveal that $\varepsilon_{b p}$ ingreases steadily with pressure. Argon gives the highest voidage, while with $\mathrm{H}_{2}$ only a very weak increase of $E_{\text {bp }}$ with pressure was found.

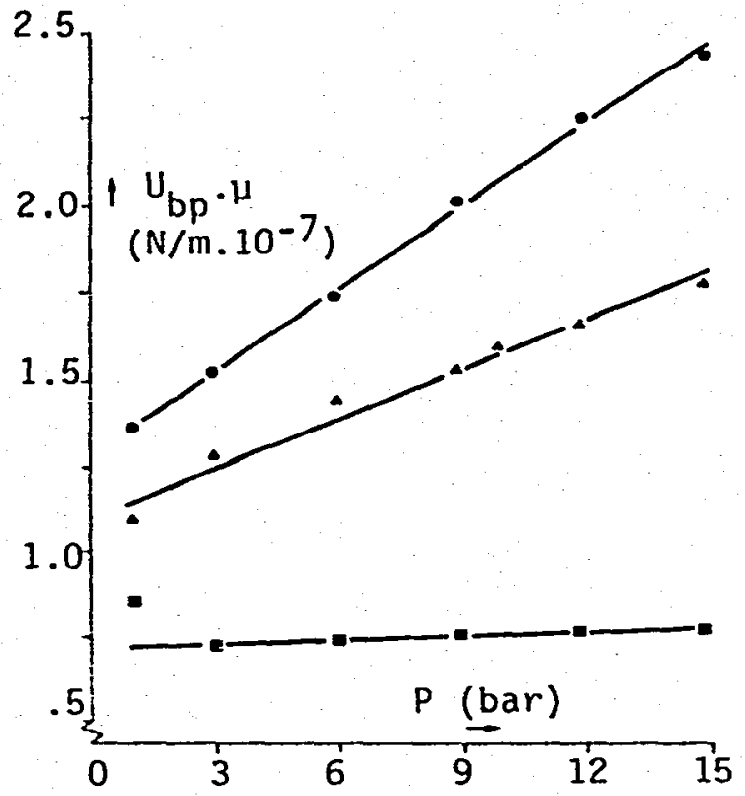

Figure 6

The variation of $U_{k p} \cdot \mu$ with pressure $\left(A A_{3}, B^{P} N_{2}, H_{2}\right)$.

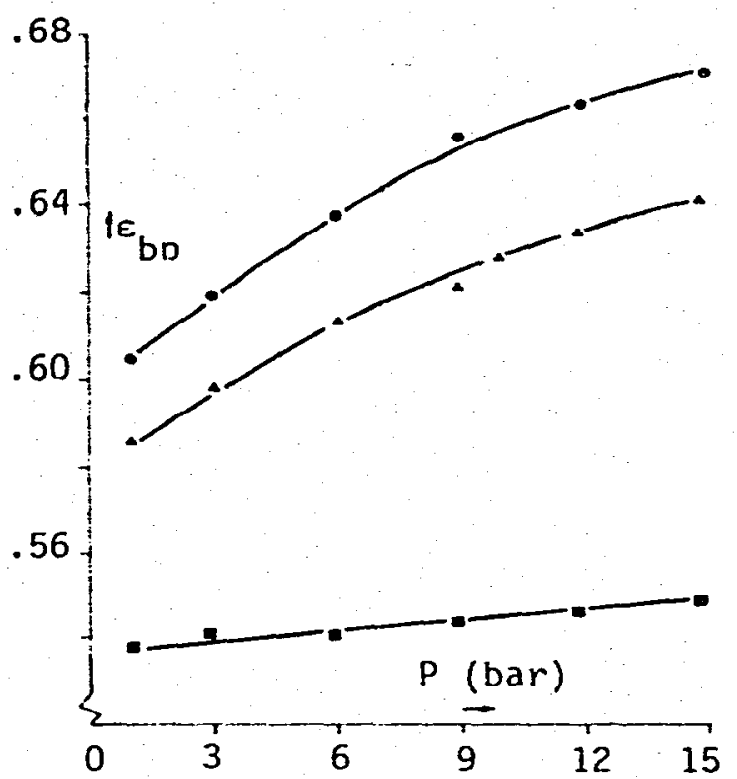

Eigure ?

The variation of $E_{b p}$ with pressure. $\left(\bullet A r, \Delta N_{2}, H_{2}\right)^{p}$

In figure 8 the bed height at the bubble point velocity, $H_{b 0}$, is given as function of the gas density. In this figure the values calculated with the correlation of Abrahamsen and Geldart [11] are also given. It can be seen that the dependence on the gas density given by this correlation is too low.

Bubbling bed

Voidage of the dense phase $\left(E_{d}\right)$ and dense phase gas velocity (U $\left.U_{d}\right)$

With $\mathrm{Ar}$ and $\mathrm{H}_{2}$ a series of collapse experiments were done for superficial gas vefocities between 2 and $5 \mathrm{~cm} / \mathrm{s}$ and at pressures up to 15 bar.

From these experiments $\varepsilon_{d}$ and $U_{d}$ were determined. The results are given in table 2. It can be seen that for the same gas velocity $\varepsilon_{d}$ and $U_{d}$ increase with increasing pressure and $\varepsilon_{d}$ and $U_{d}$ are always higher for Ar than for $\mathrm{N}_{2}$. At low pressures the values of $\varepsilon_{\mathrm{d}}$ and $\mathrm{U}_{\mathrm{d}}$ decrease with increasing superficial gas velocity. However, at increasing pressure the values are almost constant for all gas velocities. This is in agreement with the results of other authors $[8,18]$. 


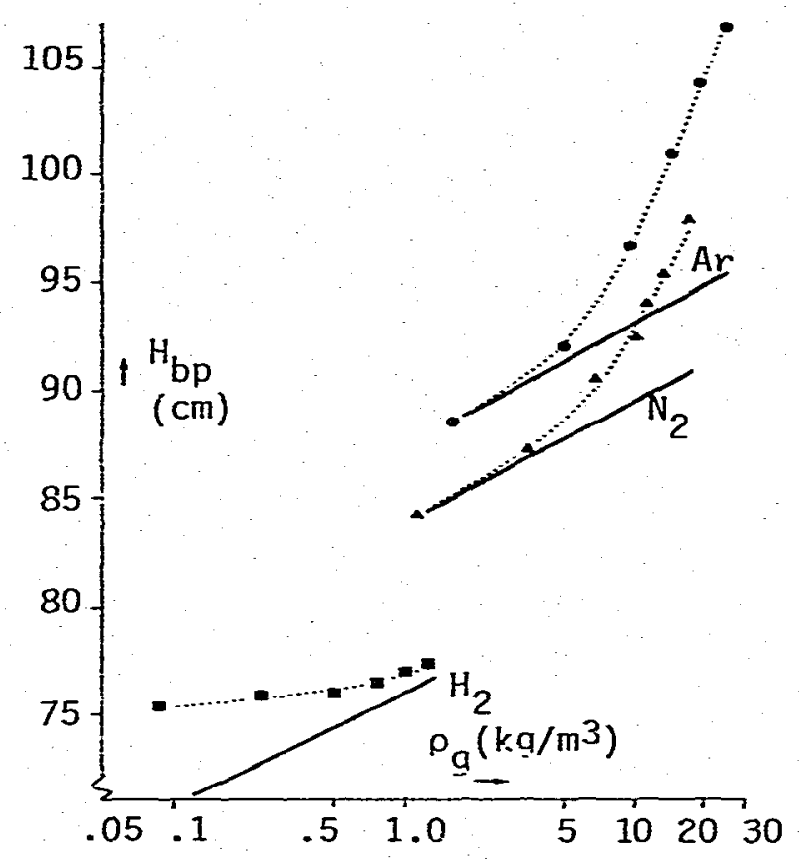

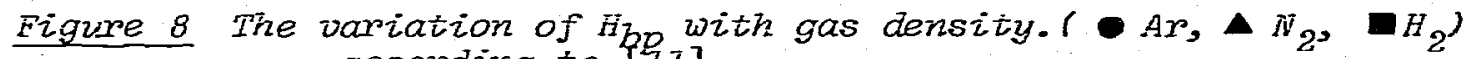

According to the correlation for the dense phase height, $H_{d}$, proposed by Abrahamsen and Geldart [18] $\mathrm{H}_{\mathrm{d}}$ should increase with gas density according to $\rho 0.016$. This means that $H_{d}$ should increase with $4.5 \%$ with an increase in pressure from 1 bar to 15 bar. However, the results reveal that the actual increase is $28 \%$ for $\mathrm{Ar}$ and $21 \%$ for $\mathrm{N}_{2}$. The dependence on the pressure or gas density given by this correlation is again far too low.

Bubble phase properties $\left(\delta, f, U_{b o}, \bar{U}_{b}, \bar{D}_{b}\right)$

The simplest model for a bubbling fluidized bed is the two-phase theory, which assumes $\varepsilon_{\mathrm{d}}=\varepsilon_{\mathrm{f}}$ and that all the gas in excess of that required for minimum fluidization passes through the bed as bubbles. The validity of this assumption has been questioned by several authors and Rietema [16] among others suggested that for fine powders during bubbling the dense phase has a higher voidage than that at $U_{\text {mf }}$ :

Under very minimal assumptions Rietema and 01trogge [19] have derived that regardless of solids flow pattern around the bubble or occurrence of a bubble cloud the total gas flow balance can be written as

$$
\mathrm{U}_{\mathrm{o}}=(1+2 \delta) \mathrm{U}_{\mathrm{d}}+\delta \overline{\mathrm{U}}_{\mathrm{b}}
$$

From the collapse experiments the bubble hold-up, $\delta$, is determined as funcition of the superficial gas velocity, $U_{0}$, and the pressure for $A r$ and $\mathrm{N}_{2}$. With the values of $\delta$ and the corresponding values of the dense phase gas velocity $U_{d}$, the superficial bubbile velocity $U_{b o}=\delta \bar{U}_{b}$ and the mean rise velocity of the bubbles $\bar{U}_{b}$ could be calculated. 
With the capacitive probe the bubble frequency, $f$, was measured at a height of $65 \mathrm{~cm}$ above the gas distributor, for the same conditions under which also the collapse experiments were performed.

With the values of the measured bubble frequency, $f$, and the superficial bubble velocity, $U_{b o}$, a mean bubble diameter can be estimated.

If we assume that the mean diameter of the bubbles is $\bar{D}_{b}$ and the number of bubbles rising per square meter per second equals $\mathrm{N}$ it follows:

$$
\begin{aligned}
& f=N * \pi \bar{D}_{b}^{2} \\
& U_{b o}=N * \pi / 6\left(\bar{D}_{b}{ }^{3}\right)
\end{aligned}
$$

Hence for the mean bubble diameter $\bar{D}_{b}$ we get:

$$
D_{b}=\frac{6 \times u_{b o}}{f}
$$

The results of the measurements and calculations are given in table 2 . The results show -as expected- an increasing bubble hold-up with increasing gas velocity. The bubble hold-up did not show significant differences for $\mathrm{Ar}$ and $\mathrm{N}_{2}$ and there is an overall increase in with increasing pressure. The superficial bubble velocity, $\mathrm{u}_{\text {bo }}$, shows an increase with increasing gas velocity and $U_{\text {bo }}$ decreases with pressure. This is mainly due to the fact that $U_{d}$ increases with pressure. The lower values of $\mathrm{U}_{\text {bo }}$ for $A r$ than for $\mathrm{N}_{2}$ are also due to the higher dense phase gas velocity, $\mathrm{U}_{\mathrm{d}}$, for Ar. The same holds for the mean bubble rise velocity, $\bar{U}_{b}$, though the effect here is not so pronounced. At higher pressures $\bar{U}_{\mathrm{h}}$ becomes more or less constant for gas velocities of $3 \mathrm{~cm} / \mathrm{s}$ and higher. Contrary to the bubble hold-up, $\delta$, the bubble frequency, $f$, strongly increases with pressure and always a higher frequency was measured for Ar than for $\mathrm{N}_{2}$.

According to equation (8) a decreasing $U_{b}$ and an increasing frequency with pressure yields a decreasing bubble $\mathrm{g}_{i}$ ameter, $\overline{\mathrm{D}}_{\mathrm{b}}$, with pressure. It can be seen from table 2 that the bubble diameter for Ar is smaller than for $\mathrm{N}_{2}$ and for both gases there is an decrease in $\overline{\mathrm{D}}_{\mathrm{b}}$ with pressure. For the highest gas velocity the decrease in bubile diameter is about a factor 3 to 4 in the measured pressure range. The effect of pressure on bubbling behaviour is in agreement with the results of other authors $[5,8,9,12-14]$ who reported smaller bubbles at higher pressures.

\section{Discussion}

The elasticity modulus $E$

The results (figures 6,7 anci 8 ) indicate that the homogeneous bed expansion, $H_{b p}$, and so $\varepsilon_{b p}$ and $U_{b p}$ increase with pressure and that the increase is trongly affected by the kind of gas used.

This means that the mechanical structure of the powder bed can withstand higher disruptive forces at increasing pressure before the powder bed becomes unstable. This can only be the result of higher interparticle forces at higher pressures.

From the theory of Rietema and Mutsers [1,2] it follows that no bubbling occurs as long as: 


\begin{tabular}{|c|c|c|c|c|c|c|c|}
\hline \multirow{2}{*}{$\Rightarrow \frac{i}{\hat{E}}$} & $\stackrel{c}{z}$ & 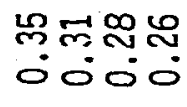 & 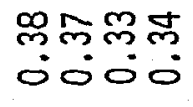 & $\begin{array}{l}\text { \&守守 } \\
\dot{000} 0\end{array}$ & 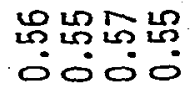 & $\begin{array}{l}\text { 过它它 } \\
00000\end{array}$ & 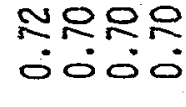 \\
\hline & $\approx$ & 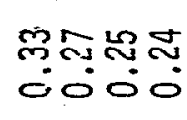 & 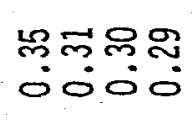 & 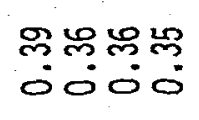 & $\begin{array}{l}\text { 孛尔多 } \\
0000\end{array}$ & 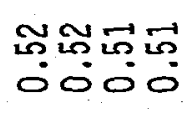 & 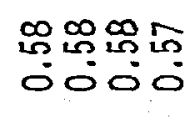 \\
\hline \multirow{2}{*}{$\omega \hat{1}$} & 文 & 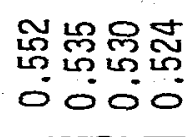 & 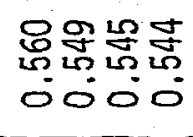 & 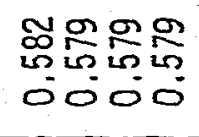 & $\begin{array}{l}\text { 형요 } \\
0000 \\
000\end{array}$ & 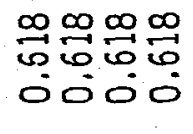 & 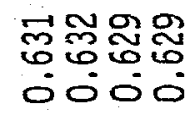 \\
\hline & $z^{N}$ & $\begin{array}{l}\text { 정ㅇㅇㅇㅇ } \\
000 \\
000\end{array}$ & 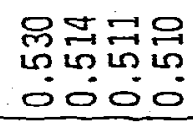 & 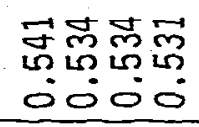 & 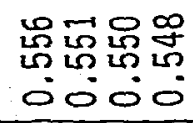 & 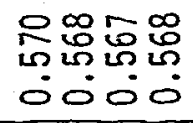 & 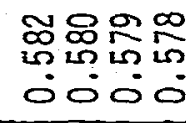 \\
\hline \multirow{2}{*}{ مـ } & 文 & صُ & 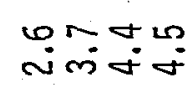 & gñnim & 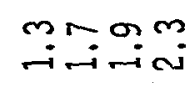 & $\begin{array}{l}\text { molo } \\
\text { minio }\end{array}$ & 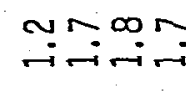 \\
\hline & $z^{N}$ & 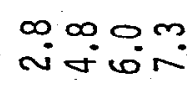 & " & 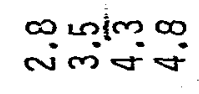 & 舟苾安 & & 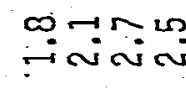 \\
\hline \multirow{2}{*}{$+\frac{\pi}{E}$} & 文 & लंmँं & نं & 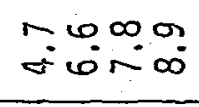 & +No & का & $\begin{array}{l}\cup 000 \\
6 \infty 09 \\
\end{array}$ \\
\hline & $z^{N}$ & 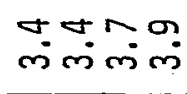 & சீசோ & mष्ण & $m$ m & $\begin{array}{l}\infty N 00 \\
\dot{\sigma} N \infty\end{array}$ & 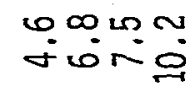 \\
\hline \multirow{2}{*}{$=\frac{\overparen{E}}{\underline{E}}$} & $\frac{2}{2}$ & هึ & 보유요 & 쿵유요 & 舟守守 & 吕孔守守 & 함워웅워 \\
\hline & 2 & 용묘용 & 명도요 & 웡영묭 & 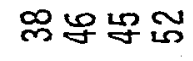 & 曲舟果 & gి $\mathscr{y}$ \\
\hline \multirow{2}{*}{$\stackrel{\circ}{=}$} & 文 & 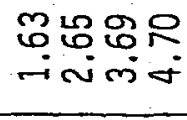 & 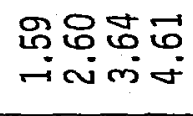 & 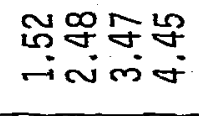 & 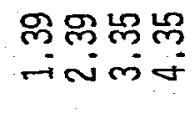 & 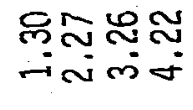 & 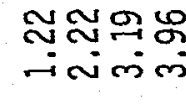 \\
\hline & $z^{N}$ & 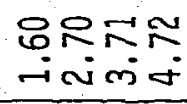 & 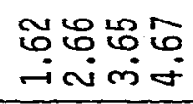 & $\begin{array}{l}\text { no요요 } \\
\text { - }\end{array}$ & 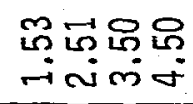 & 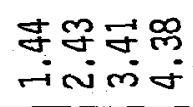 & 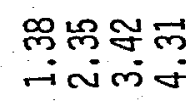 \\
\hline \multirow[t]{2}{*}{$=\widehat{D}$} & 这 & moO & $\ddot{m} \dot{0}$ & 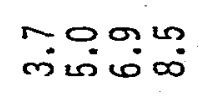 & " & 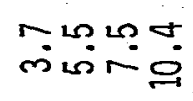 & 舟 \\
\hline & $\sum^{\infty}$ & Nign: & $m \infty 0$ & minn & 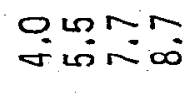 & mோன் & س \\
\hline \multirow[t]{2}{*}{$9^{\circ}$} & $\frac{n}{\hat{E}}$ & NMOL & NMOL & $N m+n$ & NMUL & Nmם & $N m \sigma m$ \\
\hline & 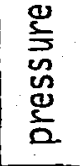 & $\begin{array}{l}\frac{1}{50} \\
\stackrel{0}{0} \\
\rightarrow\end{array}$ & $\begin{array}{l}\frac{1}{8} \\
0 \\
m\end{array}$ & $\begin{array}{l}5 \\
0 \\
0 \\
0\end{array}$ & $\frac{\frac{\pi}{\pi}}{\sigma}$ & 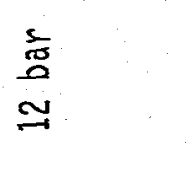 & 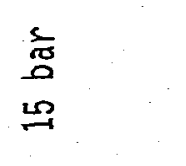 \\
\hline
\end{tabular}




$$
\left.\frac{\rho_{d}{ }^{3} d_{p}^{4} g^{2}}{\mu^{2} E_{b p}} \leq \mid \frac{150\left(1-\varepsilon_{b p}\right)}{\varepsilon_{b p}^{2}\left(3-2 \varepsilon_{b p}\right)}\right\}^{2}
$$

With the measured values of $E_{b p}$ the elasticity modulus $E_{b p}$ was calculated for the different pressufes and fluidization gases used, according to the above equation. The results of these calculation are given in figure 9. From this figure it can be seen that $F_{\text {bu }}$ increases with

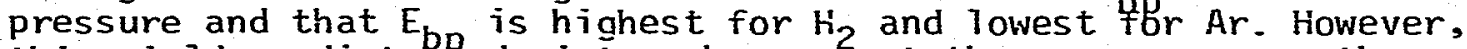
this yields a distorfed picture because at the same pressure the voidage $\varepsilon_{b p}$ is very different (figure ?) for the three gases used.

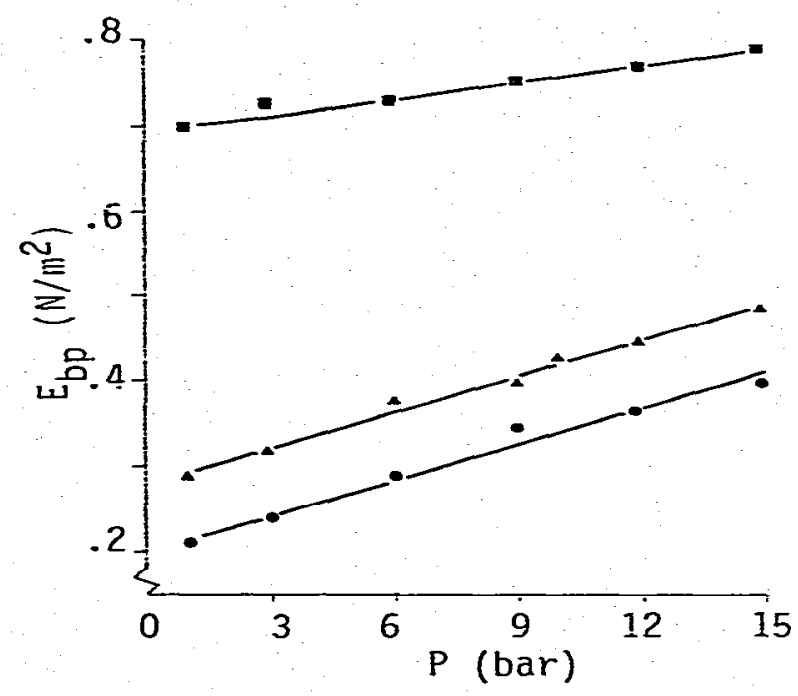

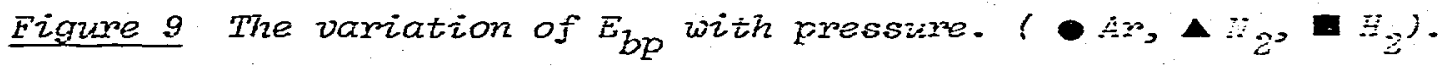

According to Mutsers and Rietema [2] E decreases exponentially with the bed voidage. The same holds also for the cohesion constant and the tensile strength as is known from powder mechanics [20,21]. To compare the elasticity modulus at different pressures the values of $E_{\text {bp }}$
(figure 9) must be extrapolated to the same porosity value.

If we assume that at ambient pressure the effect of the gas adsorption can be neglected we get for the dependence of $E$ on the porosity $\Sigma:$ $E=E_{0} \exp \left[17.9\left(\varepsilon_{o}-E\right)\right]$.

According to this equation the elasticity modulus $E_{40}$ was calculated for a bed voidage $\varepsilon_{j}=0.40$. The results of the calculations are shown in figure 10. It can be seen that both pressure and fluidizing gas have a strong influence on the elasticity modulus $E_{40}$. With Ar as fluidizing gas the values of $E_{40}$ are higher and also the increase with pressure is stronger than for $\mathrm{N}_{2}$. With $\mathrm{H}_{2}$ orly a very weak dependence on pressure was found.

The results are consistent with the dependence of $U_{b p}$ and $\varepsilon_{b p}$ (figures 6 and 7) on pressure and type of fluidization gas. Aphigher lasticity modulus $E$ means that the powder structure can withstand higher disruptive forces, which results in a higher $\varepsilon_{b p}$ and higher bubb? $\varepsilon_{\text {point }}$ velocities $\mathrm{U}_{\mathrm{bp}}$. 


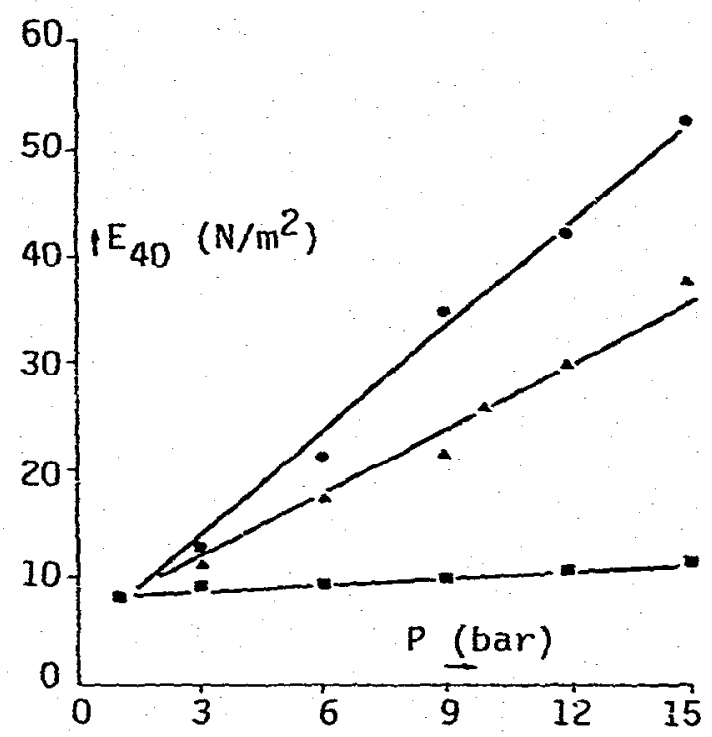

Figure 10 The variation of $E_{40}$ with pressure. ( Ar, A $\mathrm{N}_{2}, \mathrm{H} \mathrm{H}_{2}$ ).

Cohesion constant as runction of the pressure

Because the elasticity modulus, $E_{3}$ is the result of the mechanical strength of the powder structure and therefore of the interparticle cohesion forces there must be a relation between the elasticity modulus, $E$, and the cohesion constant, $C$.

The influence of pressure on the cohesion and the coefficient of friction was measured in the tilting bed in an atmosphere of Ar for pressures up to 11 bar.

Classical Coulumb theory assumes the yield locus to be linear and the following relation describes it mathematicaliy:

$$
\tau=C+\tan \phi * \sigma
$$

In the experiments with cracking catalyst a Coulomb behaviour was found for normal stresses down to $4 \mathrm{~N} / \mathrm{m}^{2}$. From a plot of $\tau$ against $a$ the cohesion constant $C$ and the friction coefficient tan $\phi$ could be determined.

The results are given in figure 11. It can be seen that the coefficient of friction tan $\phi$ decreases with increasing pressure. However, the cohesior constant increases with pressure.

The increasing cohesion constant $C$ must result in an increasing elasticity modulus, $E$, which is in agreement with the results given in figure 10 .

\section{Gas adsorption to the solid}

It is not exactly known which mechanism causes the cohesion to increase and so the elasticity modulus with increasing pressure. However, by increasing the pressure not only the gas density is changed but the amount of adsorbed gas to the solid can also be influenced. With a differential pressure technique the adsorption of $\mathrm{Ar}, \mathrm{H}_{2}$ and $\mathrm{N}_{2}$ to the solid was measured at pressures up to 15 bar. 
The results of these measurements are given in figure 12 and it can be seen that with $\mathrm{H}_{2}$ only a relatively small amount of gas is adsorbed which increases a little with pressure. However, the adsorption of Ar and $\mathrm{N}_{2}$ is considerably greater and the influence of pressure is stronger.

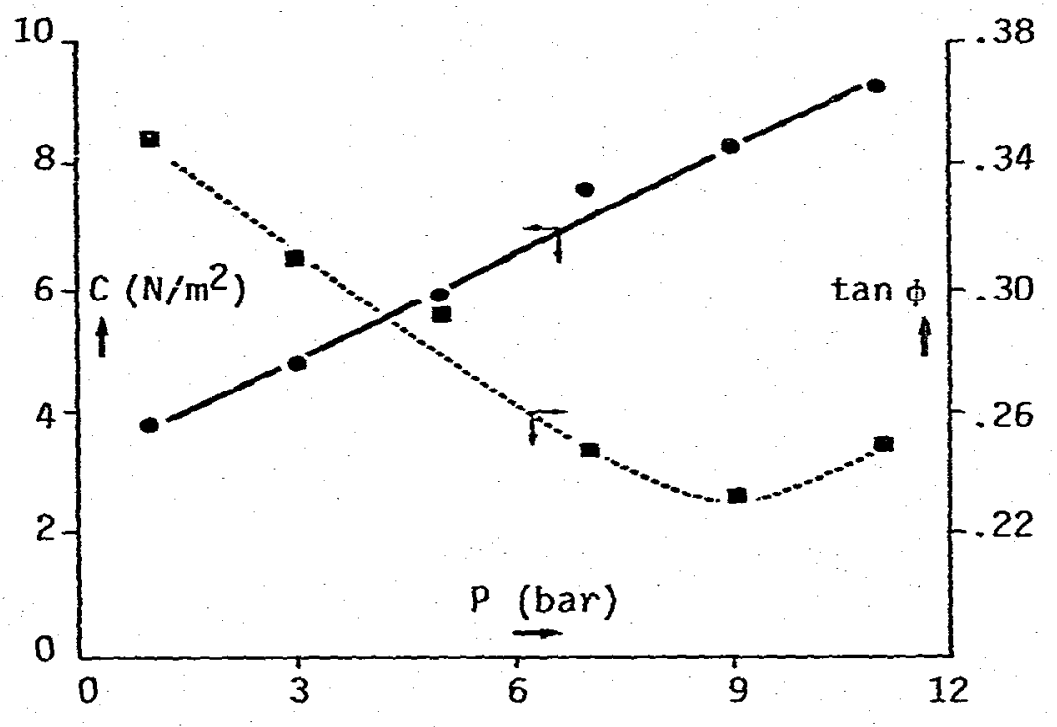

Figure 11 The variation of the cohesion constant $C$ and tan 6 with pressure for Ar.

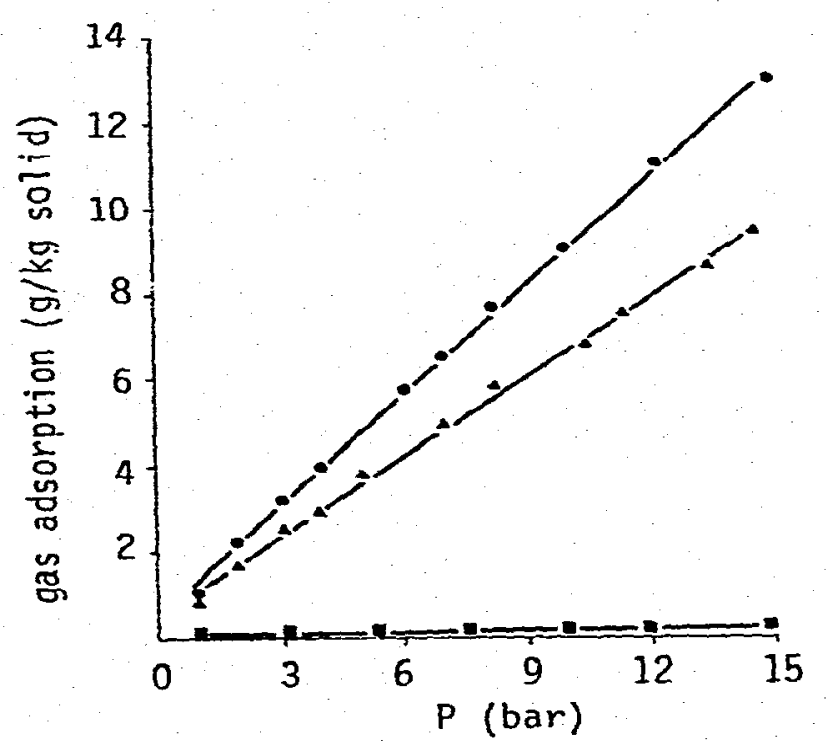

Figure 12 The variation of gas adsomption to the solid with pressure. $\left(-A r_{1} \triangle \mathrm{N}_{2}, \mathrm{H}_{2}\right)$.

Comparing figures 10,11 and 12 it can be seen that both the elasticity modulus $E_{40}$, the cohesion constant $C$ and the gas adsorption show the same trend with pressure, namely increasing with increasing pressure. 
The foregoing can be summarized as follows: due to the adsorption of gas the cohesion between the particles increases. It should be expected, therefore, that the elasticity modulus $\mathrm{E}_{40}$, which is related to the cohesion force, also increases with increasing gas adsorption at higher pressures and this explains the higher bed expansion, $\mathrm{H}_{b p}$, at higher pressures.

\section{Bubbling bed properties}

The effect of pressure on bubbling in fine powders has been studied by Guedes de Carvalho et a]. [9] and they found that up to 6 bar the total bed expansion was constant and thereafter the expansion increases significantiy. They explain this by postulating that there is a higher bubble hold-up, $\delta$, caused by smaller bubbles which rise slowly. The maximum bubble size observed in the bed did not exceed $2 \mathrm{~cm}$ even at the largest velocities. They interpreted this as an indication that larger bubbles are not stable in the bed.

Subzwari et al. [12] a]so found that the total bed expansion was constant bejow 6 bar. Their data showed, however, that the bubble hold-up, the bubble frequency and the bubble size decrease with increasing pressure. They discount the theory of Guedes de Carvalho [9] and suggest that the increased total bed expansion must be due to a higher average dense phase voidage, $\varepsilon_{\mathrm{d}}$, with increasing pressure. They explain the smaller bubbles in terms of increased bubble splitting by Taylor instabilities connected with the increased dense phase expansion. However, our results indicate that the total bed expansion, $H_{m}$, is not constant below 6 bar, but that the total bed expansion increases with pressure from 1 to 15 bar. Contrary to the results of Subzwari et al. [12] the bubble hold-up does not decrease but steadily increases with pressure.

The increasing total bed expansion is not only the result of an increasing bubble hold-up [9] but is also due to a higher dense phase voidage, $\varepsilon_{\text {d }}$ with increasing pressure.

In contrast with the findings of Guedes de Carvatho [9] the bubble size did exceed $2 \mathrm{~cm}$. However, for both $\mathrm{Ar}$ and $\mathrm{N}_{2}$ the bubble size decreases with increasing pressure. Although the decrease in bubble size with pressure becomes less at higher pressures, the results do not indicate a stable bubble size.

\section{Conclusions}

The "quality" of fluidization of abed of fine cracking catalyst improves with pressure but is also dependent on the type of fluidization gas used.

This can be explained by an increasing elasticity modulus $E$ of the powder structure with increasing pressure.

The higher elasticity moduius $E$ is the result of an increase of the cohesion between the particles. his increase in cohesion is probably due to an increased gas adsorption to the solid at higher pressures.

\section{References}

1. Rietema K. and Mutsers S.M.P.: Proc.Int.Symp.on Fluidization and its Applications, Toulouse (1973) 28.

2. Mutsers S.M.P. and Rietema K.: Powder Technology 18 (1977) 239.

3. Verkooijen A.H.M., Rietema K. and Thoenes D.: Proc. 4 th Eng.Found. Conf. on Fluidization, Kashikojima, Japan (1983) to be published. 
4. Godard K. and Richardson J.F.: Inst.Chem.Eng.Symp.Ser. 30 (1968) 126.

5. Guedes de Carvalho J.R.F., King D.F. and Harrison D.: Proc.Conf. on Fluidization, Cambridge (1978) 59.

6. Sobreiro L.E.L. and Monteiro J.L.F.: Powder Technology 33 (1982)95.

7. King D.F. and Harrison D.: Trans. Inst.Chem. Eng. 60 (1982) 26.

8. Guedes de Carvatho J.R.F.: Chem. Eng.Science 36 (1981) 413.

9. Guedes de Carvalho J.R.F. and Harrison D.: Inst.Fuel Symp.Ser. 1, (1975) BT-1.

10. Geldart D.: Powder Technology 7 (1973) 285.

11. Abrahamsen A.R. and Geldart D.: Powder Technology 26 (1980) 35.

12. Subzwari M.P., Clift R. and Pyle D.L.: Proc.Conf.on Fluidization, Cambridge (1978) 50.

13. Varadi $\mathrm{T}$. and Grace J.R.: Proc.Conf.on Fluidization, Cambridge, (1978) 55 .

14. King D.F. and Harrison D.: Proc. 3rd Eng.Found.Conf.on Fluidization Henniker (1980) 101.

15. Mutsers S.M.P. and Rietema K.: Powder Technology 18 (1977) 249.

16. Rietema K.: Proc.Int.Symp. on Fluidization, Eindroven (1967) 154.

17. Ergun S.: Chem. Eng.Prog. 48 (1952) 89.

18. Abrahamsen A.R. and Geldart D.: Powder Technology 26 (1980) 47.

19. Rietema K. and 01trogge R.D.: Symp. on Fundamental and Applied Fluidization, Tampa, Florida (1968) 31E.

20. Williams J.C. and Birks A.H.: Fowder Technology 1 (1967) 199.

21. Fairley R. and Vaientin F.H.H.: Powder Technology 1 (1967) 344.

Notations

\begin{tabular}{|c|c|c|}
\hline $\begin{array}{l}\mathrm{U}_{\mathrm{u}}^{\mathrm{o}} \\
\mathrm{U}_{\mathrm{d}}^{\mathrm{bp}} \\
\mathrm{U}_{\mathrm{mf}}^{\mathrm{u} f} \\
\mathrm{U}_{\mathrm{b}}^{\mathrm{b}} \\
\mathrm{W}^{\mathrm{b}} \\
\alpha \\
\tan \phi \\
\varepsilon\end{array}$ & $\begin{array}{l}\text { area of bed } \\
\text { cohesion constant } \\
\text { mean bubble diameter } \\
\text { sauter mean diameter of particles } \\
\text { elasticity modulus } \\
\text { elasticity modulus at the bubble point } \\
\text { elasticity modulus at a bed voidage of } 0.40 \\
\text { bubble frequency } \\
\text { acceleration of gravity } \\
\text { height of bed } \\
\text { bed height at the bubble point } \\
\text { height of the dense phase } \\
\text { maximum height of the bubbling bed } \\
\text { bed height at minimum fluidization } \\
\text { bubble frequency } \\
\text { absolute pressure } \\
\text { time coordinate } \\
\text { superficial gas velocity } \\
\text { superficial gas velocity in the dense phase } \\
\text { bubble point velocity } \\
\text { minimum fluidization velocity } \\
\text { superficial bubble velocity } \\
\text { mean bubble rise velocity } \\
\text { mass of powder in the bed } \\
\text { tilting angle } \\
\text { coefficient of friction } \\
\text { bed voidage } \\
\text { voidage of the dense phase }\end{array}$ & $\begin{array}{l}{\left[\mathrm{m}^{2}\right]} \\
{\left[\mathrm{N} / \mathrm{m}^{2}\right]} \\
{[\mathrm{m}]} \\
{[\mathrm{m}]} \\
{\left[\mathrm{N} / \mathrm{m}^{2}\right]} \\
{\left[\mathrm{N} / \mathrm{m}^{2}\right]} \\
{\left[\mathrm{N} / \mathrm{m}^{2}\right]} \\
{[1 / \mathrm{s}]} \\
{[\mathrm{m} / \mathrm{s}]} \\
{[\mathrm{m}]} \\
{[\mathrm{m}]} \\
{[\mathrm{m}]} \\
{[\mathrm{m}]} \\
{[\mathrm{m}]} \\
{\left[1 / \mathrm{m}^{2}\right.} \\
{\left[\mathrm{N} / \mathrm{m}^{2}\right]} \\
{[\mathrm{s}]} \\
{[\mathrm{m} / \mathrm{s}]} \\
{[\mathrm{m} / \mathrm{s}]} \\
{[\mathrm{m} / \mathrm{s}]} \\
{[\mathrm{m} / \mathrm{s}]} \\
{[\mathrm{m} / \mathrm{s}]} \\
{[\mathrm{m} / \mathrm{s}]} \\
{[\mathrm{kg}]} \\
{[\mathrm{rad}]} \\
{[-]} \\
{[-]} \\
{[-]}\end{array}$ \\
\hline
\end{tabular}


$\varepsilon_{b p}$ voidage at the bubble point

$\varepsilon_{\mathrm{mf}}$ voidage at minimum fluidization

[-] bubble hold-up

$[-]$ bubble hold-up
shear stress

$[-]$

$\begin{array}{ll}\tau & \text { shear stress } \\ \sigma & \text { normal stress }\end{array}$

$[\mathrm{N} / \mathrm{m} 2]$

$\rho_{g} \quad$ gas density

${ }_{\mu}^{\rho} \quad$ particle density

$\left[\mathrm{N} / \mathrm{m}^{2}\right]$

$\left[\mathrm{kg} / \mathrm{m}^{3}\right]$

$[\mathrm{kg} / \mathrm{m} 3]$

$\mu^{\mathrm{P}}$ viscosity of gas

$\left[\mathrm{Ns} / \mathrm{m}^{2}\right]$ 